\title{
Biodegradation of malodorous mercaptans by a novel Staphylococcus capitis strain isolated from gas-washing wastewaters of the Tunisian Chemical Group
}

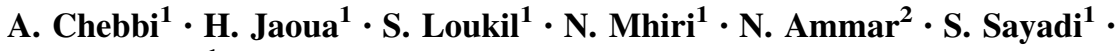 \\ M. Chamkha ${ }^{1}$
}

Received: 4 April 2015/Revised: 3 September 2015/Accepted: 22 September 2015/Published online: 8 October 2015

(C) Islamic Azad University (IAU) 2015

\begin{abstract}
There are increasing concerns over the harmful effects of the phosphate industry on human health and quality of life worldwide, including the Tunisian Chemical Group (GCT) in Sfax, which generates various malodorous gas fractions, such as hydrogen sulfide $\left(\mathrm{H}_{2} \mathrm{~S}\right)$ and fetid mercaptans, causing nuisance to employees and local residents. Accordingly, the present study aimed to investigate the ability of an adapted microbial consortium isolated from the gas-washing wastewaters (GWWs) generated from GCT to degrade hazardous and malodorous mercaptans. A novel mesophilic bacterial strain (SH6), which was noted to display particularly high mercaptan degradation potential, was isolated from the adapted consortium growing on those GWWs and several malodorous mercaptans after enrichment on 1-dodecanethiol. The results from 16 rRNA gene sequencing and identity analysis revealed that the SH6 isolate belonged to Staphylococcus genus, with a high sequence similarity to Staphylococcus capitis $(99.7 \%)$. The SH6 strain was able to completely degrade 1-dodecanethiol, used as the sole carbon and energy source, after $72 \mathrm{~h}$ of incubation at $37^{\circ} \mathrm{C}$ and $180 \mathrm{rpm}$. A decrease in the surface tension of cell-free culture supernatants was observed during the oxidation of dodecanethiol, suggesting the production of surface-active compounds. The stain was also able to grow on other mercaptans, such as 1,8 -octanedithiol and 2,3-butanedithiol, which further supports its potential
\end{abstract}

M. Chamkha

mohamed.chamkha@cbs.rnrt.tn

1 Laboratory of Environmental Bioprocesses, LMI COSYSMed, Centre of Biotechnology of Sfax, University of Sfax, PO Box 1177, 3018 Sfax, Tunisia

2 Research Center on Phosphates and Phosphoric Acid, Groupe Chimique Tunisien (GCT), BP S, 3003 Sfax, Tunisia candidacy for application in the bioremediation of mercaptan-contaminated sites. Overall, the findings of the present study indicate that the SH6 strain might offer promising opportunities for the development of more adapted, efficient and cost-effective bio-disodoration strategies.

Keywords Staphylococcus - Biodegradation · Gaswashing wastewaters $\cdot$ Fetid mercaptans $\cdot$ Phosphate fertilizer plant

\section{Introduction}

The phosphate industry has been growing at an unprecedented rate during the last few decades. This increase has been particularly driven by the rising demand for phosphate fertilizers due to the increasing demands for food supplies to nurture a growing world population and, more recently, for biofuels as renewable alternatives to fossil fuels. Although this growing industry is a major contributor to the economy of several Mediterranean countries, including Tunisia, it is associated with obnoxious solid and volatile effluents of concern for workers and the public. The Tunisian Chemical Group (GCT) of Sfax, a public company whose activity is the transformation of phosphate into solid or liquid fertilizers, has often been criticized for releasing unpleasant odors, including mercaptans (RSH) and hydrogen sulfide $\left(\mathrm{H}_{2} \mathrm{~S}\right)$, which causes nuisance to workers and local residents. These volatile organic-sulfuric compounds (VOSCs) pose serious problems to human health and the environment (Shults et al. 1970; Munday 1989; Burgess et al. 2001; Setoguchi et al. 2002). These toxic compounds can become highly disagreeable even at concentrations below their odor perception threshold 
(Tangerman 2009). Moreover, VOSCs are considered as both major sources of fetid odors even in domestic wastewater and as organic micropollutants in the environment (Khoroshko et al. 2006; Sun et al. 2014).

With these concerns in minds, recent research has become increasingly interested in the search for viable strategies to manage and control the malodorous emissions from phosphate processing and manufacturing plants (Mohanrao 1973; Ahmad et al. 2000). The GCT company has, for instance, launched a gas-washing program in its two production units, namely the phosphoric acid (PA) and triple superphosphate (TSP) units, in an attempt to reduce or remove fetid sulfur-containing compounds, such as hydrogen sulfide $\left(\mathrm{H}_{2} \mathrm{~S}\right)$ and mercaptans $(\mathrm{RSH})$, by washing gas with water.

Due to their partial solubility at lower pHs, the chemical removal of fetid sulfur-containing compounds requires large amounts of sodium hydroxide and water (Iliuta and Larachi 2007). Several studies have reported that, during bio-filtration methods, odorous contaminants are adsorbed from the air into the water present in the organic bed [i.e., bioactive layer (biofilm)] where they can be aerobically degraded to various end-products or incorporated into biomass (McNevin and Barford 2000). These findings provide support for the strategy of targeting mercaptans at their liquid state. Accordingly, there has been growing interest in the search for efficient alternative biological strategies to substitute the conventional chemical methods currently employed for the removal of fetid sulfur-containing compounds from phosphate fertilizer wastewaters.

We have previously reported on the isolation of a Bacillus licheniformis strain CAN55 from GWWs with promising abilities to oxidize heptanethiol, decanethiol, dodecanethiol and cyclohexylmercaptan as the sole carbon and energy sources at $55^{\circ} \mathrm{C}$ (Chebbi et al. 2014). We have also isolated a Brevibacillus agri strain CAT37 that was able to degrade only heptanethiol, decanethiol and dodecanethiol at $37{ }^{\circ} \mathrm{C}$ (Chebbi et al. 2015). The literature also presents other dimethyl sulfide (DMS) oxidizing strains, including Thiobacillus sp. strain MS1 (Sivela and Sundman 1975), Thiobacillus thioparus strain TK-m (Kanagawa and Mikami 1989; Treto Fernandez et al. 2013), Hyphomicrobium sp. strain VS (Fernández et al. 2013) and Hyphomicrobium sp. strain E (Suylen and Kuenen 1986). Another strain, Pseudomonas sp. strain WL2, was reported to metabolize ethyl mercaptan (ET) (Zhang et al. 2013). Paenibacillus polymyxa strain CZ05 has also been described as a methanethiol-degrader (MT) under high concentration $(60 \mathrm{ppm})$ using the bio-trickling filters $(99.5 \%)$ (Wang et al. 2014).

Despite the large flow of data on the biodegradation of $n$-alkanes, little work has for been performed on the use of $n$-alkanethiols as sole carbon and energy sources by bacteria or fungi. The isolation of efficient mercaptan-degrading microorganisms is of great interest for performing efficient and specific biological methods to eliminate mercaptans from industrial emissions and wastewaters. Accordingly, the present study was undertaken to investigate the ability of an adapted microbial consortium isolated from the gas-washing wastewaters (GWWs) generated from GCT to degrade hazardous and malodorous mercaptans. A novel mesophilic bacterial strain, designated as SH6, was isolated from the adapted consortium growing on those GWWs and several malodorous mercaptans after enrichment on 1-dodecanethiol and was noted to display particularly a high mercaptan degradation potential.

\section{Date and location of the research}

This work was performed at the Laboratory of Environmental Bioprocesses, Centre of Biotechnology of Sfax, Tunisia, between October 2010 and April 2015.

\section{Materials and methods}

\section{Sampling}

Samples of gas-washing wastewaters (GWWs) were collected from the Sfax phosphate plant of the Tunisian Chemical Group (GCT), under aseptic conditions, transferred into sterile bottles and kept in the darkness at $4{ }^{\circ} \mathrm{C}$, room temperature and $60{ }^{\circ} \mathrm{C}$.

\section{Chemicals}

Mercaptans, including 1-heptanethiol, 1-octanethiol, 1-decanethiol, 1-undecanethiol, 1-dodecanethiol, 1-tetradecanethiol, 1-pentadecanethiol, 2,3-butanedithiol, 1,8octanedithiol, cyclohexylmercaptan and 2-phenylethanethiol, were purchased from Sigma-Aldrich.

\section{Culture media}

The basal medium used in the present study consisted of $0.5 \mathrm{~g} \mathrm{KH}_{2} \mathrm{PO}_{4}, 0.4 \mathrm{~g} \mathrm{NH}_{4} \mathrm{Cl}, 0.33 \mathrm{~g} \mathrm{MgCl}_{2} \cdot 6 \mathrm{H}_{2} \mathrm{O}, 0.05 \mathrm{~g}$ $\mathrm{CaCl}_{2}, 2 \mathrm{H}_{2} \mathrm{O}, 1 \mathrm{~g} \mathrm{NaCl}$ and $1 \mathrm{~mL}$ trace-element solution (Widdel and Pfennig 1981) per liter of distilled water. The $\mathrm{pH}$ was adjusted to 7 with $10 \mathrm{M} \mathrm{NaOH}$ solution. The medium was sterilized by autoclaving at $121{ }^{\circ} \mathrm{C}$ for 20 min. The Luria-Bertani (LB) medium employed for growing and maintaining the bacterial cultures contained $10 \mathrm{~g}$ peptone, $5 \mathrm{~g}$ yeast extract and $10 \mathrm{~g} \mathrm{NaCl}$ per liter of distilled water. 


\section{Procedure of enrichments and isolation of mercaptan-degrading bacteria}

Due to the low microbial diversity of GWWs, which are characterized by a high temperature and acidic $\mathrm{pH}$, the first aerobic enrichment cultures were performed in the presence of LB medium ( $50 \mathrm{~mL})$, with the addition of $5 \mathrm{mM}$ glucose and $20 \%(\mathrm{v} / \mathrm{v})$ of GWWs used as inoculum at 37 and $55^{\circ} \mathrm{C}$, $\mathrm{pH} 4$ and 7, and $180 \mathrm{rpm}$. A positive culture $(50 \mathrm{~mL})$ containing $30 \mathrm{~mL} \mathrm{GWWs} \mathrm{(a} \mathrm{mixture} \mathrm{of} \mathrm{GWWs} \mathrm{from} \mathrm{the} \mathrm{units} \mathrm{of}$ $\mathrm{PA}$ and TSP, v/v), yeast extract $\left(0.2 \mathrm{~g} \mathrm{~L}^{-1}\right)$ and peptone $\left(0.6 \mathrm{~g} \mathrm{~L}^{-1}\right)$, at $\mathrm{pH} 7$ and $180 \mathrm{rpm}$ was used as inoculum for the screening of aerobic bacterial strains capable of degrading mercaptans. The inoculum was used at $5 \%(\mathrm{v} / \mathrm{v})$ to inoculate $50 \mathrm{~mL}$ of basal medium containing $3 \mathrm{mM}$ of 1-dodecanethiol as carbon and energy source at $37{ }^{\circ} \mathrm{C}$ and $180 \mathrm{rpm}$. The positive enrichment culture was sub-cultured under the same conditions at least five times. The microbial growth on mercaptan was monitored by measuring OD at $600 \mathrm{~nm}$ and microscopic observation. Aliquots $(100 \mu \mathrm{L})$ of $10^{-1}$ to $10^{-10}$ dilutions were taken from the positive enrichment culture on 1-dodecanethiol and plated onto agar basal medium containing $3 \mathrm{mM}$ of 1-dodecanethiol as carbon and energy source, without the addition of yeast extract. The plates were incubated at $37{ }^{\circ} \mathrm{C}$ under aerobic conditions for 3 days until colony formation. Seven colonies were picked up and serially diluted in the fresh basal medium containing the same mercaptan. Individual colonies were purified by repeated streaking on mercaptan-agar basal medium. The purity, shape and motility of the isolates were examined using a phase-contrast light microscope (Olympus BX51). Strain SH6 was noted to exhibit maximum growth on dodecanethiol and attractive biodegradation ability in the basal medium without the addition of yeast extract. The SH6 strain was, therefore, selected and maintained for further experimental assays.

\section{Growth of consortium CSH37 on GWWs}

The growth of consortium CSH37 was monitored in culture media $(50 \mathrm{~mL})$ containing various volumes of GWWs (5, 10, 20, 30 and $36 \mathrm{~mL}), 0.5 \mathrm{~g} \mathrm{~L}^{-1}$ yeast extract and $1.5 \mathrm{~g} \mathrm{~L}^{-1}$ peptone at $37^{\circ} \mathrm{C}$ and $180 \mathrm{rpm}$. Total carbon removal was examined for cultures containing $30 \mathrm{~mL}$ of GWWs incubated for 6 days with consortium CSH37 at $5 \%(\mathrm{v} / \mathrm{v}), \mathrm{pH} 7,37{ }^{\circ} \mathrm{C}$ and $180 \mathrm{rpm}$. The cultures $(0$ and 6 days) were centrifuged for $20 \mathrm{~min}$ at $4000 \mathrm{rpm}$, and the supernatants were filtered $(0.45 \mu \mathrm{m})$ and then analyzed.

\section{Characterization of strain SH6}

The Gram reaction was determined using a Gram stain Kit (BioMérieux, France) in accordance with the manufacturer's instructions. Oxidase activity was evaluated via the oxidation of $1 \% p$-aminodimethylaniline oxalate. Catalase activity was determined by the measurement of bubble production following the application of $3 \%(\mathrm{v} / \mathrm{v})$ hydrogenperoxide solution. Optimal growth temperature was determined by culture incubation at temperature values ranging between 4 and $65{ }^{\circ} \mathrm{C}$. The inoculation proportion was $5 \%$ (v/v). Various amounts of $\mathrm{NaCl}$ (from 0 to $15 \%$, w/v) were directly weighed in flasks prior to dispersing $50 \mathrm{~mL} \mathrm{LB}$ medium to determine the $\mathrm{NaCl}$ concentration desired for growth. The optimum $\mathrm{pH}$ required for growth was studied through adjusting the $\mathrm{pH}$ of the medium to a range between 3 and 11 by the addition of $5 \mathrm{M} \mathrm{HCl}$ or $10 \mathrm{M} \mathrm{NaOH}$. Optical density at $600 \mathrm{~nm}$ was monitored by growth measurements, and data from the mid-log phase growth of the strain were selected for calculating the specific growth rates. A heat resistance test was performed by incubating the cells at 80 , 90 and $100{ }^{\circ} \mathrm{C}$ for $10 \mathrm{~min}$. The cultures were then cooled quickly to ambient temperature and inoculated into fresh LB media. Growth was recorded after $24 \mathrm{~h}$ incubation at $37{ }^{\circ} \mathrm{C}$ and $180 \mathrm{rpm}$. Other phenotypic characteristics were screened by test strips of the API system (BioMérieux, France). The API Staph kit was used as described by Kloos and Wolfshohl (1982).

In order to investigate the mercaptan-degrading ability of the SH6 strain, several substrates, including 1-heptanethiol, 1-octanethiol, 1-decanethiol, 1-undecanethiol, 1-dodecanethiol, 1-tetradecanethiol, 1-pentadecanethiol, 2,3-butanedithiol, 1,8-octanedithiol, cyclohexylmercaptan and 2-phenylethanethiol, were added, at a final concentration of $3 \mathrm{mM}$, into flasks containing $50 \mathrm{~mL}$ basal medium without the addition of yeast extract. An increase in the $\mathrm{OD}_{600 \mathrm{~nm}}$ value obtained for substrate-containing cultures, as compared to control flasks lacking substrates, was considered as positive growth.

\section{S rRNA gene sequence determination and phylogenetic analysis}

The DNA was extracted from strain SH6 as described by Redburn and Patel (1993). The 16S rRNA gene of strain SH6 was amplified by PCR using a Stratagene PCR system (Robocycler gradient 96) with GoTaq DNA polymerase (Promega, WI, USA) as previously described elsewhere (Chamkha et al. 2002). The universal primers Fd1 and Rd1 (Fd1, 5'AGAGTTTGATCCTGGCTCAG-3'; Rd1, 5'-AAGGAGGTGATCCAGCC-3') (Weisburg et al. 1991) were used to obtain a PCR product of approximately $1.5 \mathrm{~kb}$ corresponding to base position 8-1542, based on Escherichia coli numbering of the 16S rRNA gene (Winker and Woese 1991). Positions of sequence and alignment ambiguity were omitted, and pairwise evolutionary distances based on 1452 unambiguous nucleotides were calculated using the method of Jukes and Cantor 
(Jukes and Cantor 1969). A dendrogram was constructed using the neighbor-joining method (Saitou and Nei 1987) with the Molecular Evolutionary Genetic Analysis (MEGA) program version 6 (Tamura et al. 2013). Confidence in the dendrogram topology was determined using 100-bootstrapped trees (Felsenstein 1985).

\section{Physicochemical analyses and analytical methods}

The $\mathrm{pH}$ and electrical conductivity (EC) of the GWWs samples were determined using a $\mathrm{pH}$ meter model IstekNeoMet and a conductivimeter model CONSORT C831, respectively. Soluble chemical oxygen demand (COD) was determined according to the method of Knechtel (1978). The five-day biological oxygen demand $\left(\mathrm{BOD}_{5}\right)$ was determined by the manometric method using a respirometer (OxiTop ${ }^{\circledR}$ Box) a described by Zayen et al. (2010). Total organic carbon was determined after dry combustion using a TOC analyzer $-V_{\mathrm{CPH}}$, SHIMADZU (Gouider et al. 2010). The phosphorus concentration in aqueous media was determined according to the vanado-molybdo-phosphoric acid spectrometry method (Gouider et al. 2010). Total Kjeldahl nitrogen content was determined as described by Kjeldahl (1883), and the hydrogen sulfide concentration was calculated according to Cord-Ruwisch and Widdel (1986). The concentration of metal ions was estimated by an atomic absorption spectrophotometer (Perkin Elmer AAnalyst 200; PerkinElmer Instruments LLC) (Hamza and Sayadi 2015).

For gas chromatography (GC) analysis, cultures of SH6 $(50 \mathrm{~mL})$ containing $3 \mathrm{mM}$ mercaptan and an abiotic control were extracted three times with dichloromethane (DCM) (Corrêa and Arbilla 2008). The organic fraction was then evaporated to dryness and dissolved in $1 \mathrm{~mL}$ of DCM. One microliter of the solution obtained was analyzed by GC using a SHIMADZU GC-17A apparatus equipped with a capillary Supelco column (length, $30 \mathrm{~m}$; internal diameter, $0.25 \mathrm{~mm}$; film thickness, $0.25 \mu \mathrm{m})$. The carrier gas was helium used at a flow rate of $1 \mathrm{~mL} \mathrm{~min}{ }^{-1}$. The temperature of the injector was fixed at $250{ }^{\circ} \mathrm{C}$. The temperature was first set at $100{ }^{\circ} \mathrm{C}$ for $2 \mathrm{~min}$ and then increased to $250{ }^{\circ} \mathrm{C}$ at $15{ }^{\circ} \mathrm{C} \min ^{-1}$.

The surface tension was measured by a Gibertini Tensiometer (TSD 132389, Milan, Italy) as previously described in the literature (Mnif et al. 2011). The values given represent the mean of three replicates ( \pm standard deviation, SD).

\section{Results and discussion}

\section{Characteristics of GWWs}

The physicochemical parameters of the GWWs collected from GCT are summarized in Table 1. The wastewater samples were characterized by an acidic $\mathrm{pH}$ (around 2), high temperature (about $60{ }^{\circ} \mathrm{C}$ ), low organic matter and high contents of phosphorus, due to the GCT processes which produced phosphoric acid and triple superphosphate. These characteristics can play an important role in impeding microbial growth and activity. The results recorded in terms of $\mathrm{COD} / \mathrm{BOD}_{5}$ values (about 2.8) indicated that the two GWWs samples contained relatively biodegradable organic pollutants (Tebbutt 1997). The literature indicates that wastewaters containing biodegradable components with $\mathrm{COD} / \mathrm{BOD}_{5}$ values ranging between 1 and 3 can be easily treated by biological processes (Tebbutt 1997; Alvarez-Vazquez et al. 2004). In the gas emissions and wastewaters of both GCT production units, the total mercaptan content ranged between 50 and $100 \mathrm{ppm}$ and did not exceed $50 \mathrm{ppm}$, respectively (Table 1). No hydrogen sulfide $\left(\mathrm{H}_{2} \mathrm{~S}\right)$ content was, however, detected in the wastewater samples. In fact, the acidic character and high temperature of the wastewater samples could presumably have inhibited the solubility of hydrogen sulfide (Millero 1986). The results also revealed that iron was present in comparatively higher concentration than other heavy metals such as copper, nickel and manganese (Table 1). This could presumably be attributed to the use of gypsum, $\mathrm{Ca}_{3}\left(\mathrm{PO}_{4}\right)_{2} \mathrm{CaF}_{2}$, in the phosphoric acid production process. Overall, the results showed the GWWs samples generated from the phosphoric acid and triple superphosphate units exhibited several similarities. Accordingly, and in order to increase the chances of obtaining a wider range of mercaptan-degrading bacteria, both GWWs samples were equally mixed (v/v) during the enrichment procedures.

\section{Enrichment cultures and isolation of mercaptan- degrading bacteria}

Several thermophilic $\left(55^{\circ} \mathrm{C}\right)$ and mesophilic $\left(37^{\circ} \mathrm{C}\right)$ microbial enrichment cultures were performed at $\mathrm{pH} 4$ and pH 7 and monitored at aerobic conditions to adapt the consortia growing on the GWWs samples. The results revealed the absence of microbial growth in the acidic enrichment cultures. Microbial growth remained mostly low at $55{ }^{\circ} \mathrm{C}$ and $\mathrm{pH} 7{ }^{\circ} \mathrm{C}$. The mesophilic enrichment culture showed better microbial growth results, with a bacterial population generally having bacilli and cocci shapes.

The strategy followed in the present study was to increase the volume of the wastewater and decrease the amounts of other nutriments in the culture media so as to ensure the optimal adaptation of microorganisms to those GWWs samples and broaden the chances to screen a wide range of mercaptan-degrading bacteria. Microbial growth was monitored in the presence of various volumes of GWWs by measuring $\mathrm{OD}_{600 \mathrm{~nm}}$ at different culture time 
Table 1 Physicochemical characteristics of gas-washing wastewaters

\begin{tabular}{|c|c|c|}
\hline Characteristics & Unit of phosphoric acid & Unit of TSP \\
\hline $\mathrm{pH}\left(25^{\circ} \mathrm{C}\right)$ & 2.18 & 1.30 \\
\hline Electrical conductivity $\left(\mathrm{mS} \mathrm{cm}{ }^{-1}\right)$ & 8.93 & 39.53 \\
\hline Salinity $\left(\mathrm{g} \mathrm{L}^{-1}\right)$ & 6.76 & 33.60 \\
\hline $\operatorname{COD}\left(\mathrm{mg} \mathrm{L}^{-1}\right)$ & 170 & 140 \\
\hline $\mathrm{BOD}_{5}\left(\mathrm{mg} \mathrm{L}^{-1}\right)$ & 60 & 50 \\
\hline $\mathrm{COD} \mathrm{BOD}_{5}$ & 2.83 & 2.8 \\
\hline \multicolumn{3}{|l|}{ TOC } \\
\hline Total carbon $\left(\mathrm{mg} \mathrm{L}^{-1}\right)$ & 104.30 & 77.9 \\
\hline Organic carbon $\left(\mathrm{mg} \mathrm{L}^{-1}\right)$ & 103.5 & 76.00 \\
\hline Inorganic carbon $\left(\mathrm{mg} \mathrm{L}^{-1}\right)$ & 0.80 & 1.90 \\
\hline $\mathrm{TKN}\left(\mathrm{mg} \mathrm{L}^{-1}\right)$ & 29.40 & 25.20 \\
\hline Phosphorus $\left(\mathrm{PO}_{4}\right)\left(\mathrm{mg} \mathrm{L}^{-1}\right)$ & 100.66 & 74.34 \\
\hline Phosphorus pentoxide $\left(\mathrm{P}_{2} \mathrm{O}_{5}\right)$ & 2.28 & 1.69 \\
\hline Total mercaptans in wastewaters $(\mathrm{ppm})^{\mathrm{a}}$ & $<50$ & $<50$ \\
\hline Total mercaptans in gas emissions $(\mathrm{ppm})^{\mathrm{a}}$ & $50-100$ & $50-100$ \\
\hline $\mathrm{H}_{2} \mathrm{~S}(\mathrm{mM})$ & 0 & 0 \\
\hline \multicolumn{3}{|l|}{ Ions and heavy metals $\left(\mathrm{mg} \mathrm{L}^{-1}\right)$} \\
\hline Sodium (Na) & 493.1 & 480.2 \\
\hline Calcium $(\mathrm{Ca})$ & 234 & 177.2 \\
\hline Magnesium (Mg) & 87.6 & 77.5 \\
\hline Potassium (K) & 35.8 & 33.1 \\
\hline Iron $(\mathrm{Fe})$ & 5.213 & 3.293 \\
\hline Copper $(\mathrm{Cu})$ & 0.077 & 0.221 \\
\hline Nickel (Ni) & 0.001 & 0.006 \\
\hline Manganese (Mn) & 0.091 & 0.038 \\
\hline Lead $(\mathrm{Pb})$ & 0 & 0 \\
\hline
\end{tabular}

TSP triple superphosphate, TKN total Kjeldahl nitrogen

${ }^{a}$ Data were obtained from the GCT (Groupe Chimique Tunisien), Sfax, Tunisia points (Fig. 1). The GWWs were used as carbon and energy sources. The results revealed that growth occurred even in the presence of $36 \mathrm{~mL}$ of wastewaters $(72 \%$, v/v). Optimum growth was observed with the addition of $10 \mathrm{~mL}$ of wastewaters $(20 \%, \mathrm{v} / \mathrm{v})$, with an $\mathrm{OD}_{600 \mathrm{~nm}}$ value of about 0.6 being recorded after 3 days of incubation at $37{ }^{\circ} \mathrm{C}$. Appropriate growth conditions were particularly observed with the culture medium containing $30 \mathrm{~mL}$ GWWs $\left(60 \%\right.$, v/v), which yielded an $\mathrm{OD}_{600 \mathrm{~nm}}$ value of about 0.4 after 3 days of incubation. The latter culture medium, designated as consortium CSH37, was selected and maintained for further investigation (Fig. 1).

The total organic carbon (TOC) was determined for cultures growing on $60 \%(\mathrm{v} / \mathrm{v})$ GWWs for 6 days at $37^{\circ} \mathrm{C}, \mathrm{pH} 7$ and $180 \mathrm{rpm}$. After 6 days of incubation, the TOC values decreased by almost $34 \%$ from 2577 to $1691 \mathrm{mg} \mathrm{L}^{-1}$. This could presumably be attributed to the oxidation of organic matter by the $\mathrm{CSH} 37$ bacterial

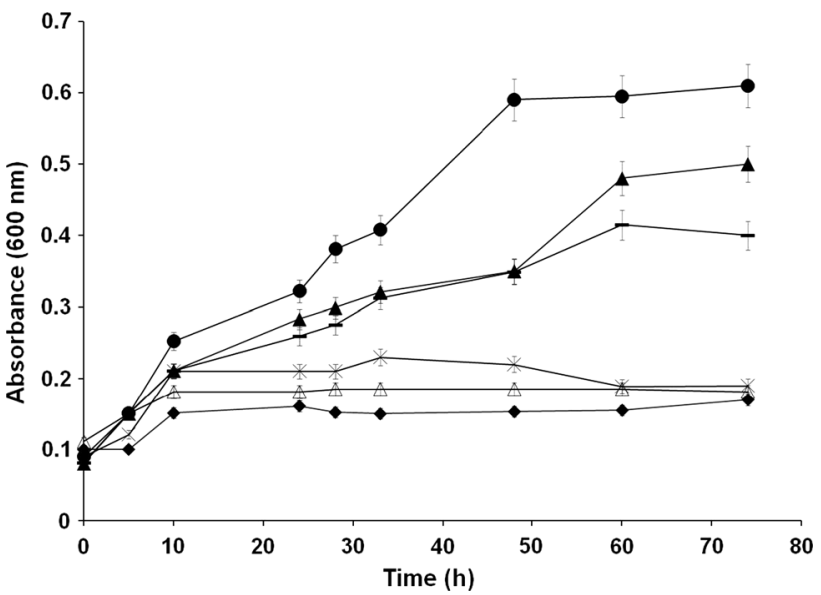

Fig. 1 Growth of the microbial consortium CSH37 in the presence of various amounts of gas-washing wastewaters at $37{ }^{\circ} \mathrm{C}$ and $180 \mathrm{rpm}$; (filled diamond) $0 \mathrm{~mL}$; (times) $5 \mathrm{~mL}$; (filled circle) $10 \mathrm{~mL}$; (filled triangle) $20 \mathrm{~mL}$; (dash) $30 \mathrm{~mL}$; (open triangle) $36 \mathrm{~mL}$ 
consortium and its potential to grow on the sulfur-containing compounds in those wastewaters.

A stable microbial population was noted to develop after several dilutions and sub-culturing in the basal medium containing $3 \mathrm{mM}$ of dodecanethiol used as the sole carbon and energy source, with the morphological dominance of a non-motile, spherically shaped and non-spore-forming bacterium. This enrichment culture was serially diluted and used to inoculate Petri dishes containing $3 \mathrm{mM}$ dodecanethiol. Seven colonies were picked, and the pure SH6 strain was selected for further characterization on the basis of its capacity to grow on $3 \mathrm{mM}$ of 1-dodecanethiol in liquid and solid media, without yeast extract added.

\section{Characterization of strain SH6}

The results revealed that the SH6 strain was aerobic, Grampositive, coccus, non-motile and non-spore-forming bacterium that occurred individually, in pairs and in tetrads. The findings indicated the occurrence of catalase production, but absence of oxidase formation. Agar colonies formed after overnight culture. They were generally circular, slightly convex, smooth, opaque, glossy and with a diameter of 1-2 $\mathrm{mm}$. Strain SH6 was able to grow over a temperature range of $25-55{ }^{\circ} \mathrm{C}$, with optimum growth at $37^{\circ} \mathrm{C}$. No growth was, however, noted to occur at 4 and $65{ }^{\circ} \mathrm{C}$. The $\mathrm{NaCl}$ concentration required for growth was ranged between 0 and $120 \mathrm{~g} \mathrm{~L}^{-1}$, with an optimum at $10 \mathrm{~g} \mathrm{~L}^{-1}$. The initial $\mathrm{pH}$ range required for growth was $\mathrm{pH}$ $5-10$, with an optimum at $\mathrm{pH} 7$. No growth occurred at $\mathrm{pH}$ 3.3 or 11 . The major phenotypic characteristics obtained from the API Staph are presented in Table 2. The 16S rRNA gene sequence of strain SH6, comprising 1452 nucleotides, was determined and deposited in the GenBank nucleotide database under accession number KP455742. Phylogenetic analysis indicated that strain SH6 was most closely related to members of the genus Staphylococcus, particularly species of Staphylococcus capitis ATCC $27840^{\mathrm{T}}$ (Bannerman and Kloos 1991), with a sequence similarity of $99.72 \%$ (Fig. 2). The differential phenotypic characteristics of strain SH6 and its closest neighbors in the genus Staphylococcus are illustrated in Table 2.

Table 2 Differential phenotypic characteristics of the strain SH6 and other related type strains of the genus Staphylococcus

\begin{tabular}{|c|c|c|c|c|}
\hline Characteristics & Strain SH6 & $\begin{array}{l}\text { Staphylococcus capitis } \\
\text { (Kloos and Schleifer 1975) }\end{array}$ & $\begin{array}{l}\text { Staphylococcus epidermidis } \\
\text { (Hugh and Ellis 1968) }\end{array}$ & $\begin{array}{l}\text { Staphylococcus aureus } \\
\text { (La Fuente et al. 1985) }\end{array}$ \\
\hline Similarity 16S rRNA with SH6 (\%) & 100 & 99.72 & 99.23 & 98.34 \\
\hline Gram & + & + & + & + \\
\hline Oxidase & - & - & $\mathrm{v}$ & - \\
\hline Catalase & + & + & + & + \\
\hline Non-motile & + & + & + & + \\
\hline $\mathrm{NaCl}$ growth range $\left(\mathrm{g} \mathrm{L}^{-1}\right)$ & $0-120$ & $0-100$ & $0-75$ & $0-100$ \\
\hline Growth at $15 \% \mathrm{NaCl}$ & + & + & - & + \\
\hline Temperature growth range $\left({ }^{\circ} \mathrm{C}\right)$ & $25-55$ & $18-45$ & $15-45$ & $10-45$ \\
\hline Growth at $15^{\circ} \mathrm{C}$ & ND & - & - & + \\
\hline Growth at $45^{\circ} \mathrm{C}$ & + & + & + & + \\
\hline $\mathrm{pH}$ growth range & $5-10$ & ND & ND & $4.2-9.3$ \\
\hline Urease & - & - & + & $+1-$ \\
\hline Arginine dihydrolase & + & + & + & + \\
\hline \multicolumn{5}{|l|}{ Assimilation of } \\
\hline D-Glucose & + & + & + & + \\
\hline D-Fructose & + & + & + & + \\
\hline D-Mannose & + & + & + & + \\
\hline Maltose & + & - & + & + \\
\hline Lactose & - & - & + & + \\
\hline D-Trehalose & - & - & - & + \\
\hline D-Mannitol & - & $+1-$ & - & + \\
\hline Xylitol & - & - & - & - \\
\hline Raffinose & - & - & - & - \\
\hline Xylose & - & - & - & - \\
\hline Saccharose & + & + & + & + \\
\hline
\end{tabular}

ND not determined, $v$ variable 
Fig. 2 Phylogenetic tree based on 1452 16S rRNA gene sequence showing the position of strain SH6 among related species of the genus Staphylococcus. Genbank accession members are given in parentheses. Escherichia coli is used as an out group. Numbers at the nodes indicate the percentages of bootstrap samplings. Bar 1 substitution per 100 nucleotides

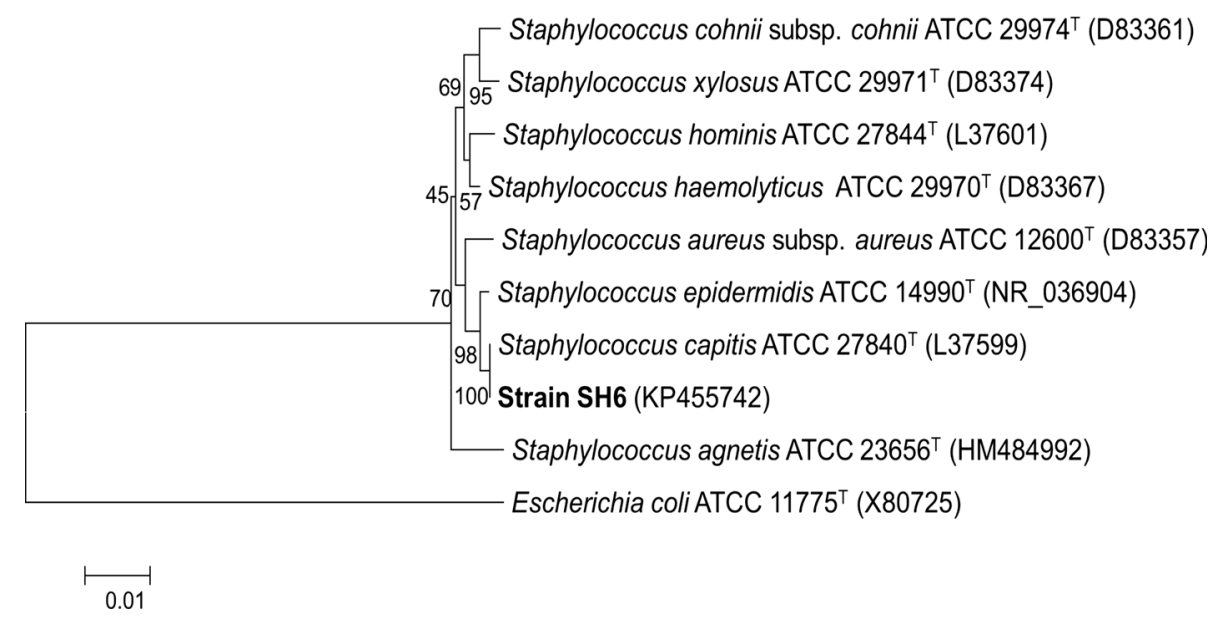

\section{Biodegradation of dodecanethiol by strain SH6}

Strain SH6 was grown aerobically at $37{ }^{\circ} \mathrm{C}$ on $3 \mathrm{mM}$ dodecanethiol as the sole carbon and energy source. Aliquots were withdrawn from the culture medium at different time intervals and submitted to GC analysis. The results displayed in Fig. 3 indicate a change in biomass and dodecanethiol content during the cultivation of strain SH6. The dodecanethiol degradation rate showed an increase during the log phase of growth, reaching approximately $82 \%$ after $9 \mathrm{~h}$ of incubation (Fig. 3). Dodecanethiol was completely removed after $72 \mathrm{~h}$ of incubation (Fig. 3). During the dodecanethiol biodegradation process, and owing to the increased cell density, the $\mathrm{OD}_{600 \mathrm{~nm}}$ value increased to approximately 1, thus indicating that the SH6 strain utilized dodecanethiol as a carbon source for growth. The effect of dodecanethiol concentration on the growth of strain SH6 was also studied by measuring the specific

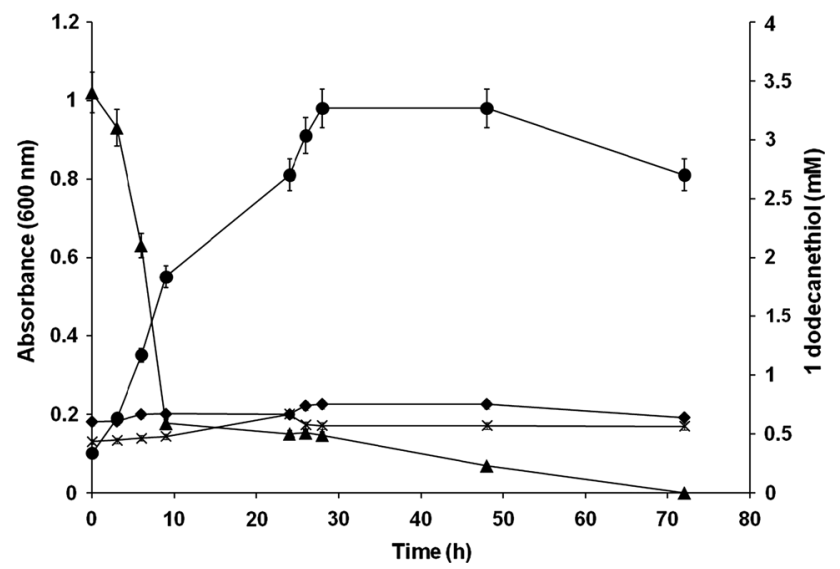

Fig. 3 Aerobic growth of strain SH6 in basal medium containing $3 \mathrm{mM}$ dodecanethiol at $37{ }^{\circ} \mathrm{C}$ and $180 \mathrm{rpm}$. (Filled circle) absorbance at $600 \mathrm{~nm}$; (filled triangle) concentration of 1-dodecanethiol; (times) biological control; (filled diamond) abiotic control of 1-dodecanethiol growth at a concentration range between 0 and $30 \mathrm{mM}$ (Fig. 4). Strain SH6 was able to grow over a broad range of dodecanethiol concentration, ranging between 1 and $10 \mathrm{mM}$, with optimum growth being recorded in the presence of $3 \mathrm{mM}$ dodecanethiol (Fig. 4). At $20 \mathrm{mM}$, the growth was completely inhibited, suggesting the toxicity of this compound (Fig. 4).

Several studies have previously highlighted the promising potential of using Staphylococcus spp. in biodegradation and bioremediation processes. The Staphylococcus auriculans strain DBF63 was reported for its ability to grow on dibenzofuran $\left(\mathrm{C}_{12} \mathrm{H}_{8} \mathrm{O}\right)$ or fluorene $\left(\mathrm{C}_{13} \mathrm{H}_{10}\right)$ as the sole carbon and energy source (Monna et al. 1993). The Staphylococcus sp. strain PN/Y, isolated from petroleum-contaminated soils, was also described to have the ability to grow on phenanthrene as the sole carbon and energy source (Mallick et al. 2007; Mallick and Dutta 2008). Moreover, Staphylococcus arlettae strain VN-11, which was isolated from an activated sludge of a textile industry, was reported to decolorize four different azo dyes under microaerophilic conditions (Elisangela et al. 2009). Likewise, three isolates belonging to Staphylococcus

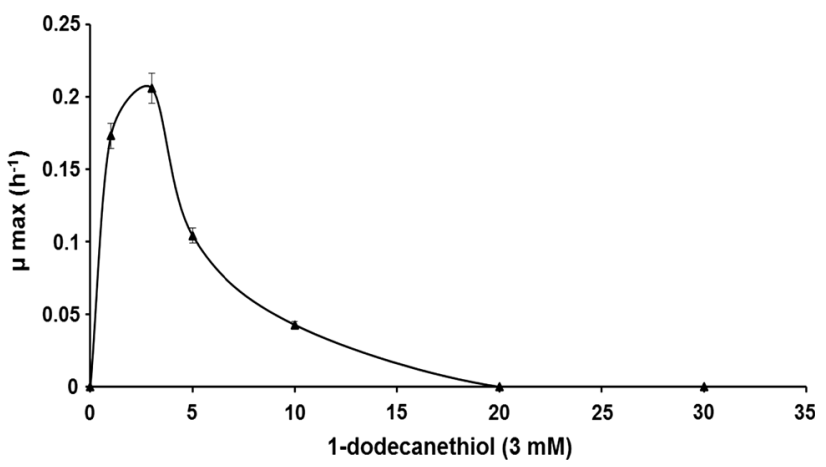

Fig. 4 Effect of 1-dodecanethiol concentration on growth of strain SH6 at $37^{\circ} \mathrm{C}$ and $180 \mathrm{rpm}$ 


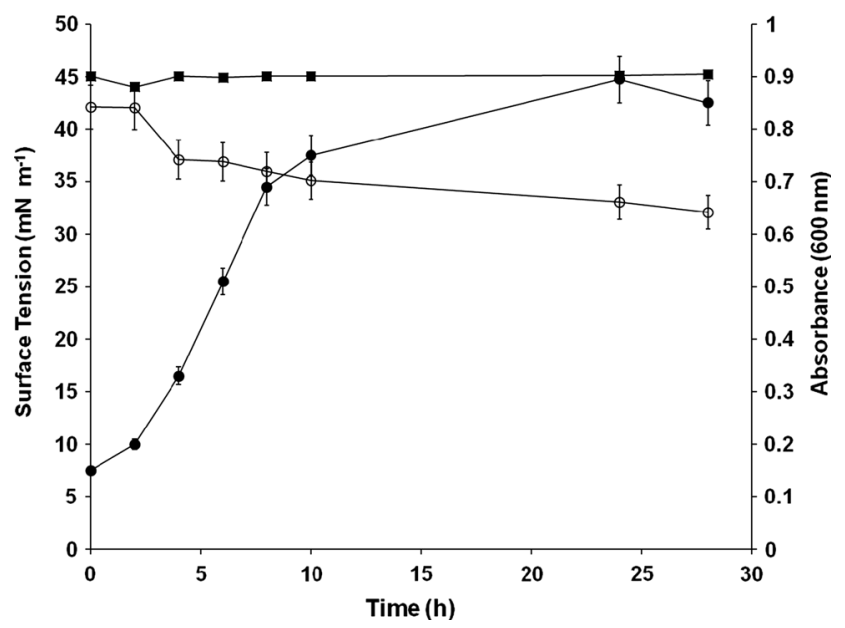

Fig. 5 Surface tension variation during the growth of the strain SH6 on the basal medium containing $3 \mathrm{mM}$ of 1 -dodecanethiol at $37{ }^{\circ} \mathrm{C}$ and $180 \mathrm{rpm}$. (Open circle) surface tension of the culture SH6; (filled square) surface tension of the abiotic control; (filled circle) absorbance at $600 \mathrm{~nm}$ of culture SH6

saprophyticus, Staphylococcus epidermidis and Staphylococcus capitis were identified from selected consortia growing on several polyaromatic hydrocarbons (PAHs) as sole carbon sources (Bidaud and Tran-Minh 1998). Some strains of the genus Staphylococcus used linear $n$-alkanes as a sole source of carbon and energy (Walker et al. 1976; Pineda-Flores et al. 2004). In addition, Staphylococcus sp. strains 36-GP and 64-GP were identified in a microbial consortium capable of mineralizing asphaltenes (PinedaFlores et al. 2004). The present study is the first to report on a Staphylococcus capitis strain capable of using mercaptan as a substrate for growth in basal medium, which was previously isolated from several hydrocarbon-contaminated sites.

Furthermore, the results revealed that the SH6 isolate was able to reduce the surface tension of the cell-free medium from 42.2 to $32.2 \mathrm{mN} \mathrm{m}^{-1}$ during growth on dodecanethiol after $28 \mathrm{~h}$ of incubation at $37^{\circ} \mathrm{C}$ and $180 \mathrm{rpm}$ (Fig. 5). This suggested that strain SH6 was able to produce biosurfactant(s), thus increasing the solubility and bioavailability of mercaptans. Similarly, Bacillus licheniformis strain CAN55 was previously reported to reduce the surface tension during growth on 1-decanethiol and 1-dodecanethiol used as sole carbon and energy sources at $55{ }^{\circ} \mathrm{C}$ (Chebbi et al. 2014). These molecules could, therefore, have enhanced the dispersion and biodegradation of mercaptans and facilitated their assimilation through microbial cells. In fact, Staphylococcus sp. strain 1E was previously reported to show a relative potential to degrade hydrocarbons and, simultaneously, an interesting ability to produce surface-active compounds (Eddouaouda et al. 2012). The biosurfactant production by a Staphylococcus hominis strain, using weathered diesel as a low-cost raw material, was also reported (Mariano et al. 2008). Little work was, however, performed to investigate the biosurfactant(s) produced by the genus of Staphylococcus as well as other genera such as Bacillus and Pseudomonas. To the authors' knowledge, the present study is the first to report on the secretion of biosurfactants by Staphylococcus capitis species growing on mercaptan.

\section{Biodegradative potential on other mercaptans}

The ability of strain SH6 to degrade other mercaptans without the addition of yeast extract was also investigated. Growth was monitored by $\mathrm{OD}_{600 \mathrm{~nm}}$ measurements and microscopic observations. The SH6 strain was able to grow on 1-dodecanethiol $\left(\mathrm{C}_{12} \mathrm{H}_{25} \mathrm{SH}\right), \quad$ 1,8-octanedithiol $\left(\mathrm{C}_{8} \mathrm{H}_{16}(\mathrm{SH})_{2}\right)$ and 2,3-butanedithiol $\left(\mathrm{C}_{4} \mathrm{H}_{8}(\mathrm{SH})_{2}\right)$, reaching $1,0.7$ and 0.4 after $24 \mathrm{~h}$ of incubation at $37{ }^{\circ} \mathrm{C}$ and $180 \mathrm{rpm}$, respectively. The strain was, however, not able to grow on 1-heptanethiol, 1-decanethiol, 1-undecanethiol, 1-tetradecanethiol, 1-pentadecanethiol, cyclohexylmercap$\tan$ and 2-phenylethanethiol, indicating affinity with specific mercaptan structures. These results are in agreement with the study performed with Bacillus licheniformis strain CAN55, which showed ability to grow only on specific sulfur-containing compounds (Chebbi et al. 2014). In fact, $n$-alkanes biodegradation by bacterial strains was previously reported to depend on molecular weights and structures (Grund et al. 1975). Based on this variability, the investigation of the biodegradation of various mercaptans by a mixture of bacterial strains could expand current knowledge on the range of target substrates. In fact, the targeting of specific chemical structures and use of appropriate microorganisms have previously been reported as fundamental strategies for the biological treatment of malodorous compounds (Rappert and Muller 2005). The enhancement of thiol solubility in aqueous media seems also to offer a promising strategy to obtain higher biodegradation rates. In fact, $n$-alkanes have been described to represent recalcitrant insoluble compounds that are hard to degrade by bacteria or fungi (Haritash and Kaushik 2009; Bisht et al. 2014). Accordingly, further research is needed to investigate the potential association between $n$ alkanes biodegradation and $n$-alkanethiols.

\section{Conclusion}

The present study was undertaken to investigate the ability of an adapted microbial consortium isolated from the gaswashing wastewaters (GWWs) generated from GCT to degrade hazardous and malodorous mercaptans. The GWWs samples were characterized by acidic $\mathrm{pH}$ and low 
biodegradable organic matter. A bacterial consortium (CSH37) showed particular ability to grow on these wastewaters and several mercaptans and was, therefore, selected and maintained for further investigation. A bacterial strain SH6 was isolated from the CSH37 consortium after enrichment on dodecanethiol. This strain was affiliated to Staphylococcus capitis based on phenotypic and phylogenetic characteristics. Strain SH6 was able to degrade dodecanethiol used as a sole carbon and energy source. The strain was also noted to induce a reduction in the surface tension of the cell-free culture supernatants, thus suggesting its ability to produce surface-active compounds (biosurfactant(s)). Accordingly, further studies are needed to investigate the nature of these surface-active agents and their effects on mercaptans. Due to its possible human pathogenicity as the great majority of hydrocarbondegrader genera (e.g., Pseudomonas spp.), safety and hazardous investigations are required before large-scale applications in industrial sites. Overall, the results presented in this work could contribute to the current knowledge on the biodegradation of fetid mercaptans generated by phosphate fertilizer plants. They indicate that the SH6 strain and CSH37 consortium could offer promising candidates for use in large-scale applications involving the treatment of specific sulfuric compounds. More research is, however, needed to determine the genes responsible for this microbial biodegradation.

Acknowledgments This work was supported by grants from the Tunisian ministry of higher education and scientific research, the Groupe Chimique Tunisien (GCT) and Research Center of Sfax, Tunisia. The authors would like to express their gratitude Mr. Adel Gargoubi for his technical assistance in CPG analyses and Mrs. Sonia Kchaou for her help in the Test strips of the API system. They would also like to thank Mr. Anouar Smaoui and Mrs. Hanen Ben Salem from the English Language Unit at the Faculty of Science of Sfax, Tunisia, for their valuable proofreading and language polishing services.

\section{Compliance with ethical standards}

Conflict of interest The authors declare that they have no conflict of interest.

\section{References}

Ahmad I, Ali S, Jan MR (2000) Physico-chemical analysis of fertilizer industry effluent and its effects on crop plants. Pak J Sci Ind Res 43:83-89

Alvarez-Vazquez H, Jefferson B, Judd SJ (2004) Membrane bioreactors vs conventional biological treatment of landfill leachate: a brief review. J Chem Technol Biotechnol 79:1043-1049

Bannerman TL, Kloos WE (1991) Staphylococcus capitis subsp. ureolyticus subsp. nov. from human skin. Int J Syst Bacteriol 41:144-147

Bidaud C, Tran-Minh C (1998) Polycyclic aromatic hydrocarbons (PAHs) biodegradation in the soil of a former gasworks site: selection and study of PAHs-degrading microorganisms. J Mol Catal B Enzym 5:417-421

Bisht S, Pandey P, Kaur G et al (2014) Utilization of endophytic strain Bacillus sp. SBER3 for biodegradation of polyaromatic hydrocarbons (PAH) in soil model system. Eur J Soil Biol 60:67-76

Burgess JE, Parsons SA, Stuetz RM (2001) Developments in odour control and waste gas treatment biotechnology: a review. Biotechnol Adv 19:35-63

Chamkha M, Record E, Garcia JL et al (2002) Isolation from a shea cake digester of a tannin-tolerant Escherichia coli strain decarboxylating p-hydroxybenzoic and vanillic acids. Curr Microbiol 44:341-349

Chebbi A, Mnif S, Mhiri N et al (2014) A moderately thermophilic and mercaptan-degrading Bacillus licheniformis strain CAN55 isolated from gas-washing wastewaters of the phosphate industry, Tunisia. Int Biodeterior Biodegrad 94:207-213

Chebbi A, Mhiri N, Rezgui F et al (2015) Biodegradation of malodorous thiols by a Brevibacillus sp. strain isolated from a Tunisian phosphate factory. FEMS Microbiol Lett 362:10

Cord-Ruwisch R, Widdel F (1986) Corroding iron as a hydrogen source for sulphate reduction in growing cultures of sulphatereducing bacteria. Appl Microbiol Biotechnol 25:169-174

Corrêa SM, Arbilla G (2008) Mercaptans emissions in diesel and biodiesel exhaust. Atmos Environ 42:6721-6725

Eddouaouda K, Mnif S, Badis A et al (2012) Characterization of a novel biosurfactant produced by Staphylococcus sp. strain 1E with potential application on hydrocarbon bioremediation. J Basic Microbiol 52:408-418

Elisangela F, Andrea Z, Fabio DG et al (2009) Biodegradation of textile azo dyes by a facultative Staphylococcus arlettae strain VN-11 using a sequential microaerophilic/aerobic process. Int Biodeterior Biodegrad 63:280-288

Felsenstein J (1985) Confidence limits on phylogenies: an approach using the bootstrap. Evolution (N Y) 39:783-789

Fernández HT, Rico IR, Prida JJDL, Van Langenhove H (2013) Dimethyl sulfide biofiltration using immobilized Hyphomicrobium VS and Thiobacillus thioparus TK-m in sugarcane bagasse. Environ Technol (U K) 34:257-262

Gouider M, Feki M, Sayadi S (2010) Bioassay and use in irrigation of untreated and treated wastewaters from phosphate fertilizer industry. Ecotoxicol Environ Saf 73:932-938

Grund A, Shapiro J, Fennewald M et al (1975) Regulation of alkane oxidation in Pseudomonas putida. J Bacteriol 123:546-556

Hamza M, Sayadi S (2015) Valorisation of olive mill wastewater by enhancement of natural hydroxytyrosol recovery. Int J Food Sci Technol 50:826-833

Haritash AK, Kaushik CP (2009) Biodegradation aspects of polycyclic aromatic hydrocarbons (PAHs): a review. J Hazard Mater 169:1-15

Hugh R, Ellis MA (1968) The neotype strain for Staphylococcus epidermidis (Winslow and Winslow 1908) Evans 1916. Int J Syst Bacteriol 18:231-239

Iliuta MC, Larachi F (2007) Solubility of total reduced sulfurs (hydrogen Sulfide, methyl mercaptan, dimethyl sulfide, and dimethyl disulfide) in liquids. J Chem Eng Data 52:2-19

Jukes TH, Cantor CR (1969) Evolution of protein molecules. In: Munro HN (ed) Mammalian Protein Metabolism. Academic Press, New York, pp 21-132

Kanagawa T, Mikami E (1989) Removal of methanethiol, dimethyl sulfide, dimethyl disulfide, and hydrogen sulfide from contaminated air by Thiobacillus thioparus TK-m. Appl Environ Microbiol 55:555-558

Khoroshko LO, Petrova VN, Takhistov VV et al (2006) Sulfur organic compounds in bottom sediments of the eastern Gulf of Finland. Environ Sci Pollut Res Int 14:366-376 
Kjeldahl J (1883) Neue methode zur bestimmung des stickstoffs in organischen kerpern. Z Anal Chem 22:366-382

Kloos WE, Schleifer KH (1975) Isolation and characterization of Staphylococci from human skin II. Descriptions of four new species: Staphylococcus warneri, Staphylococcus capitis, Staphylococcus hominis, and Staphylococcus simulans. Int J Syst Bacteriol 25:62-79

Kloos WE, Wolfshohl JF (1982) Identification of Staphylococcus species with the API Staph-Ident system. J Clin Microbiol 16:509-516

Knechtel RJ (1978) A more economical method for the determination of chemical oxygen demand. J Water Pollut Control 116:25-29

La Fuente RD, Suarez G, Schleifer KH (1985) Staphylococcus aureus subsp. anaerobius subsp. nov., the causal agent of abscess disease of sheep. Int J Syst Bacteriol 35:99-102

Mallick S, Dutta TK (2008) Kinetics of phenanthrene degradation by Staphylococcus sp. strain $\mathrm{PN} / \mathrm{Y}$ involving 2-hydroxy-1-naphthoic acid in a novel metabolic pathway. Process Biochem 43:1004-1008

Mallick S, Chatterjee S, Dutta TK (2007) A novel degradation pathway in the assimilation of phenanthrene by Staphylococcus sp. strain $\mathrm{PN} / \mathrm{Y}$ via meta-cleavage of 2-hydroxy-1-naphthoic acid: formation of trans-2,3-dioxo-5-(2'-hydroxyphenyl)-pent-4enoic acid. Microbiology 153:2104-2115

Mariano AP, Bonotto DM, Angelis DF et al (2008) Use of weathered diesel oil as a low-cost raw material for biosurfactant production. Braz J Chem Eng 25:269-274

McNevin D, Barford J (2000) Biofiltration as an odour abatement strategy. Biochem Eng J 5:231-242

Millero FJ (1986) The thermodynamics and kinetics of the hydrogen sulfide system in natural waters. Mar Chem 18:121-147

Mnif S, Chamkha M, Labat M, Sayadi S (2011) Simultaneous hydrocarbon biodegradation and biosurfactant production by oilfield-selected bacteria. J Appl Microbiol 111:525-536

Mohanrao GJ (1973) Pollution in fertiliser industry. Indian J Environ Health 15:255-268

Monna L, Omori T, Kodama T (1993) Microbial degradation of dibenzofuran, fluorene, and dibenzo-p-dioxin by Staphylococcus auriculans DBF63. Appl Environ Microbiol 59:285-289

Munday R (1989) Toxicity of thiols and disulphides: involvement of free-radical species. Free Radic Biol Med 7:659-673

Pineda-Flores G, Boll-Argüello G, Lira-Galeana C, Mesta-Howard AM (2004) A microbial consortium isolated from a crude oil sample that uses asphaltenes as a carbon and energy source. Biodegradation 15:145-151

Rappert S, Muller R (2005) Microbial degradation of selected odorous substances. Waste Manag 25:940-954

Redburn AC, Patel BKC (1993) Phylogenetic analysis of Desulfotomaculum thermobenzoicum using polymerase chain reactionamplified 16S rRNA-specific DNA. FEMS Microbiol Lett 113:81-86

Saitou N, Nei M (1987) The neighbor-joining method: a new method for reconstructing phylogenetic trees. Mol Biol Evol 4:406-425
Setoguchi T, Machigashira M, Yamamoto M et al (2002) The effects of methyl mercaptan on epithelial cell growth and proliferation. Int Dent J 52(Suppl 3):241-246

Shults WT, Fountain EN, Lynch EC (1970) Methanethiol poisoning: irreversible coma and hemolytic anemia following inhalation. JAMA 211:2153-2154

Sivela S, Sundman V (1975) Demonstration of Thiobacillus type bacteria, which utilize methyl sulphides. Arch Microbiol 103:303-304

Sun J, Hu S, Sharma KR et al (2014) An efficient method for measuring dissolved VOSCs in wastewater using GC-SCD with static headspace technique. Water Res 52:208-217

Suylen GM, Kuenen JG (1986) Chemostat enrichment and isolation of EG. A dimethyl-sulphide oxidizing methylotroph and reevaluation of Thiobacillus MS1. Antonie Van Leeuwenhoek 52:281-293

Tamura K, Stecher G, Peterson D (2013) MEGA6: molecular evolutionary genetics analysis version 6.0. Mol Biol Evol $30: 2725-2729$

Tangerman A (2009) Measurement and biological significance of the volatile sulfur compounds hydrogen sulfide, methanethiol and dimethyl sulfide in various biological matrices. J Chromatogr B Anal Technol Biomed Life Sci 877:3366-3377

Tebbutt THY (1997) Principles of water quality control. ButterworthHeinemann, London, pp 20-84

Treto Fernandez H, Rodriguez Rico I, Jover de la Prida J, Van Langenhove H (2013) Dimethyl sulfide biofiltration using immobilized Hyphomicrobium VS and Thiobacillus thioparus TK-m in sugarcane bagasse. Environ Technol 34:257-262

Walker JD, Colwell RR, Petrakis L (1976) Biodegradation rates of components of petroleum. Can J Microbiol 22:1209-1213

Wang X, Wu C, Liu N et al (2014) Degradation of ethyl mercaptan and its major intermediate diethyl disulfide by Pseudomonas sp. strain WL2. Appl Microbiol Biotechnol 7:3211-3220

Weisburg WG, Barns SM, Pelletier DA, Lane DJ (1991) 16S ribosomal DNA amplification for phylogenetic study. J Bacteriol 173:697-703

Widdel F, Pfennig N (1981) Sporulation and further nutritional characteristics of Desulfotomaculum acetoxidans. Arch Microbiol 129:401-402

Winker S, Woese CR (1991) A definition of the domains Archaea, Bacteria and Eucarya in terms of small subunit ribosomal RNA characteristics. Syst Appl Microbiol 14:305-310

Zayen A, Mnif S, Aloui F et al (2010) Anaerobic membrane bioreactor for the treatment of leachates from Jebel Chakir discharge in Tunisia. J Hazard Mater 177:918-923

Zhang CZ, Zhang WJ, Xu J (2013) Isolation and identification of methanethiol-utilizing bacterium CZ05 and its application in bio-trickling filter of biogas. Bioresour Technol 150:338-343 